\title{
MANAJEMEN PENGELOLAAN RETRIBUSI PASAR DALAM MENINGKATKAN PENDAPATAN ASLI DAERAH DI KOTA KENDARI
}

\author{
'La Ode Muhammad Elwan \\ ${ }^{1}$ Fakultas IImu Sosial dan IImu Politik, Universitas Halu Oleo \\ muh.elwan@uho.ac.id \\ Kendari - Indonesia
}

\begin{abstract}
This study aims to find out how the management of market retribution in increasing Regional Original Revenue in the Lapulu market Kendari City. The approach of this study is a qualitative approach with a type of descriptive qualitative research. The technique of collecting data is done through observation, interviews, and documentation. The data analysis technique used consists of data collection, data reduction, data presentation and conclusion drawing.

The results of this study indicate that: planning in terms of setting targets that have been arranged is optimal. This can be seen from the determined and implemented stages of targeting that are carried out every year, but the achievement of targets has never been fulfilled due to lack of awareness of traders or mandatory retribution in terms of paying retribution. The conclusion of the study was that the implementation of market retribution management in increasing Regional Original Revenue in the Lapulu market in Kendari City was not effective due to the lack of intensive collection of mandatory levies, delinquent payment of levies by traders for various reasons so that the realization of market retribution did not reach the planned target.
\end{abstract}

Keywords: Income; Management; Retribution

\begin{abstract}
Abstrak
Penelitian ini bertujuan untuk mengetahui Bagaimana manajemen pengelolaan retribusi pasar dalam meningkatkan Pendapatan Asli Daerah di pasar Lapulu Kota Kendari. Pendekatan penelitian ini adalah pendekatan Kualitatif dengan jenis penelitian deskriptif Kualitatif. Teknik pengumpulan data dilakukan melalui observasi, wawancara, dan dokumentasi. Teknik analisis data yang di gunakan terdiri dari pengumpulan data, reduksi data, penyajian data dan penarikan kesimpulan. Hasil penelitian ini menunjukan bahwa: perencanaan dalam hal penentuan target yang telah di susun sudah optimal. Hal ini dapat di lihat dari telah ditentukan dan dilaksanakannya tahap-tahap penentuan target yang di lakukan setiap tahun, namun pencapaian target tidak pernah terpenuhi akibat kurangnya kesadaran pedagang atau wajib retribusi dalam hal membayar retribusi. Kesimpulan dari penelitian ini adalah bahwa penerapan manajemen retribusi pasar dalam meningkatkan Pendapatan Asli Daerah di pasar Lapulu di Kota Kendari tidak efektif karena kurangnya pengumpulan pungutan wajib yang intensif, tunggakan pembayaran pungutan oleh pedagang karena berbagai alasan sehingga realisasi retribusi pasar tidak mencapai target yang direncanakan.
\end{abstract}

Kata Kunci: Manajemen; Pendapatan; Restribusi 
Vol 2 No 3 August-October 2019. pp.32-41. Journal PUBLICUHO Faculty of Social and Political Sciences Halu Oleo University, Kendari, Southeast Sulawesi, Indonesia. ISSN 2621-1351 (online), ISSN 2685-0729 (print) Open Access at:

http://ojs.uho.ac.id/index.php/PUBLICUHO/index

\section{PENDAHULUAN}

Retribusi pasar adalah pungutan daerah atau jasa pelayanan penyediaan fasilitas pasar tradisional/sederhana yang berupa halaman/pelataran, los dan kios yang dikelola Pemerintah daerah dan khusus disediakan untuk pedagang, tidak termasuk yang dikelola oleh perusahaan daerah (PD). Retribusi pasar termasuk golongan retribusi jasa umum yang tingkat penggunaan jasanya diukur berdasarkan kelas pasar, jenis tempat, luas kios, luas los, tempat dasaran/pelataran dan waktu.

Dengan demikian dapat juga dikatakan bahwa retribusi daerah merupakan pembayaran yang dipungut oleh pemerintah daerah sebagai penyelenggara perusahaan atau usaha bagi yang berkepentingan atau karena jasa yang telah diberikan oleh pemerintah daerah. Pentingnya pelaksanaan dan pengawasan dalam pengelolaan retribusi pasar pada dasarnya dimaksudkan untuk menjaga agar kegiatan dalam suatu sistem pengelolaan retribusi pasar sesuai dengan rencana yang ditentukan. Selain itu pengawasan ini ditujukan untuk mengetahui kelemahannya yang dihadapi dalam pemungatan sehingga mempengaruhi tingkat penerimaan. Berbagai kekurangan-kekurangan dapat diatasi melalui pengawasannya secara langsung maupun tidak langsung.

Pentingnya pelaksanaan pengelolaan retribusi pasar di Lapulu Kota Kendari adalah upaya pemerintah daerah dalam mengarahkan aparatnya guna melaksanakan pemungutan pajak dan tertib disiplin administrasi, pengawasan yang ketat serta dalam kesempatan itu turut memberikan pembinaan kepada masyarakat dalam meningkatkan kesadarannya membayar retribusi dan memperhatikan sarana dan prasarana yang mempengaruhi penerimaan retribusi. Untuk mencapai tujuan diatas maka keberhasilan retribusi pasar tergantung pada suatu cara pelaksanaan pemungutan retribusi yang ditentukan pemerintah daerah yang mana dalam operasionalnya dapat disesuaikan dengan kondisi kegiatan pasar. Dengan suatu cara pelaksanaannya pemungutan tersebut dapat menjadi suatu sistem pelaksanaan yang terarah pada tujuan, selain itu dapat memberikan pelayanan dan pengaturan yang baik terhadap masyarakat pemakai jasa pasar.

Kebijaksanaan fiskal merupakan salah satu instrumen yang dapat digunakan oleh pemerintah untuk mempengaruhi perekonomian suatu Negara melalui aspek penerimaan dan pengeluaran dalam anggaran negara. Secara teoritis, dampak kebijakan fiskal tersebut dapat dijelaskan dengan mekanisme multiplier. Menurut Lindaver (dalam Simanjuntak dan Mukhlis 2012) multiplier menunjukkan perubahan tingkat keseimbangan ekonomi sebagai akibat perubahan dalam salah satu komponen yang mempengaruhinya, yakni pembelian pemerintah (G), transfer (Tr), pajak (Tx), dan pinjaman vang. Oleh karena itu, setiap tingkat perubahan salah satu komponen fiskal ini akan berakibat perubahan pada keseimbangan pendapatan nasional (multiplier).(Simanjuntak dan Mukhlis 2012)

Dengan turut berperannya pemerintah daerah hal ini Dinas Pendapatan Daerah dalam peningkatan pengelolaan dan pelaksanaan kebijakan retribusi pasar maka dapat memberikan sumber penerimaan yang dapat diandalkan dalam peningkatan pendapatan asli daerah yang turut mendukung pembiayaan penyelenggaraan urusan pemerintah daerah Kota Kendari. Pelaksanaan kebijakan pemungutan retribusi pasar Lapulu Kota Kendari belum terlaksana dengan baik, sehingga pemasukan retribusi pasar tidak mencapai hasil yang diinginkan. Hal ini disebabkan masih ada masyarakat yang belum memahami pentingnya pemungutan retribusi pasar tersebut sehingga pelaksanaan pemungutan retribusi pasar secara bulanan di Pasar Lapulu Kota Kendari. Kehadiran pasar tersebut diharapkan dapat merumuskan formula dan Strategi untuk mendapatkan dana dalam menata, mengatur dan membangun sarana/prasarana perpasaran, serta diharapkan juga dapat membiayai dirinya sekaligus mendatangkan keuntungan bagi Pemerintah Kota Kendari dalam bentuk pemasukan Pendapatan Asli Daerah (PAD). 
Dari uraian latar belakang menjadi penting untuk melakukan kajian tentang Manajemen Pengeloalaan Retribusi Pasar dalam meningkatkan PAD (Studi kasus pasar Lapulu Kota Kendari).

\section{TINJAUAN PUSTAKA}

\section{Manajemen Publik}

Manajemen publik atau dapat juga disebut manajemen pemerintah secara umum merupakan suatu upaya pemerintah dalam pemenuhan kebutuhan publik dengan menggunakan sarana dan prasarana yang tersedia. Unsur manajemen saat ini menjadi suatu unsur penting dalam penyelenggaraan organisasi, baik organisasi pada sektor swasta maupun dalam sektor public seperti organisasi pemerintahan. Manajemen pada sektor publik yang diangkat dari manajemen sektor swasta tidak menjadikan orientasi tujuan dan pelaksanaan pada organisasi sektor publik menjadi sama dengan sector swasta. Mahmudi (2010:38-40) mengungkapkan ada setidaknya tujuh karakteristik manajemen sektor publik yang membedakannya dengan sektor swasta:

1. Sektor publik tidak mendasarkan keputusan pada pilihan individual dalam pasar, akan tetapi pilihan kolektif dalam pemerintahan dimana tuntutan masyarakat yang sifatnya kolektif (massa) akan disampaikan melalui perwakilannya yang dalam hal ini adalah partai politik atau DPR.

2. Penggerak sektor publik adalah karena adanya kebutuhan sumber daya, seperti air bersih, listrik, kemanan, kesehatan, pendidikan, transportasi, dan sebagainya yang menjadi alasan utama sektor publik untuk menyediakannya.

3. Dalam organisasi sektor publik, informasi harus diberikan kepada public seluas mungkin untuk meningkatkan transparansi dan akuntabilitas publik, yang artinya sektor publik sifatnya terbuka kepada masyarakat dibandingkan dengan sektor swasta.

4. Organisasi sektor publik berkepentingan untuk menciptakan adanyakesempatan yang sama bagi masyarakat untuk memenuhi kebutuhanutama hidupnya, misalnya kebutuhan terhadap kesehatan, pendidikan,transportasi dan sarana-sarana umum lainnya.

5. Sektor publik dihadapkan pada permasalahan keadilan distribusikesejahteraan sosial, sedangkan sektor swasta tidak dibebani tanggungjawab untuk melakukan keadilan seperti itu.

6. Dalam organisasi sektor publik, kekuasaan tertinggi adalah masyarakat.Dalam hal tertentu masyarakat adalah pelanggan, akan tetapi dalamkeadaan tertentu juga masyarakat bukan menjadi pelanggan.

7. Dalam sektor swasta persaingan (kompetisi) merupakan instrumentpasar, sedangkan dalam sektor publik tindakan kolektif menjadiinstrument pemerintahan. Sangat sulit bagi pemerintah untuk memenuhikeinginan dan kepuasan tiap-tiap orang dan yang mungkin dilakukanadalah pemenuhan keinginan kolektif.

Konsep manajemen publik dalam penelitian ini dipaparkan dalam 3 paradigma, yaitu sebagai berikut:

1. Old Public Administration

2. New Public Management

3. New Public Service

George R. Terry,1958 dalam bukunya Principles of Management (Sukarna, 2011: 10) membagi empat fungsi dasar manajemen, yaitu Planning (Perencanaan), Organizing (Pengorganisasian), Actuating (Pelaksanaan / pengendalian) dan Controlling (Pengawasan). Keempat fungsi manajemen ini disingkat dengan POAC.

\section{Konsep Pengelolaan}

Pengelolaan merupakan istilah yang di pakai dalam ilmu manajemen secara etimologi pengelolaan berasal dari kata "kelola" (to manage) dan biasanya merujuk pada proses mengurus atau menangani sesuatu untuk mencapai tujan. Mengelola berasal dari kata "mengelola" yang dapat di artikan dalam bentuk mengerjakan mengurus dan menyelengarakan kegiatan atau yang lebih di kenal dengan istilah manajemen. Pengelolaan sama dengan prinsip manajemen yang berkaitan dengan 4 aspek manajemen 
Vol 2 No 3 August-October 2019. pp.32-41. Journal PUBLICUHO Faculty of Social and Political Sciences Halu Oleo University, Kendari, Southeast Sulawesi, Indonesia. ISSN 2621-1351 (online), ISSN 2685-0729 (print) Open Access at:

http://ojs.uho.ac.id/index.php/PUBLICUHO/index

yaitu perencanaan, pengorganisasian, pelaksanaan, dan pengawasan serta pemanfaatan sumber daya termasuk sumber daya manusia untuk mencapai suatu tujuan organisasi.

Tujuan pengelolaan akan tercapai jika langkah-langkah dalam pelaksanaan pengelolaan berdasarkan tujuan sebagai berikut:

a) Menentukan strategi

b) Menentuka sarana dan batsan tanggung jawab,

c) Menentukan target yang mencakup kriteria hasil kualitas dan batasan waktu

d) Menentukan pengoperasian tugas dan rencana

e) Menentukan standar kerja yang mencakup efektivitas dan efisiensi

f) Menentukan ukuran untuk menilai

g) Mengadakan penilaian

h) Mengadakan review secara berkala

i) Pelaksanaan tahap berikutnya berlansung berulang-ulang

Marry Parker Follet (dalam Mustafa L. \& Elwan L.O.M;2018 : 18-31) mendefinisikan pengelolaan adalah seni atau proses dalam menyelesaikan sesuatu yang terkait dengan pecapaian tujuan. Dalam penyelesaian akan sesuatu tersebut, terdapat tiga faktor yang terlibat yakni 1) adanya penggunaan sumber daya organisasi, baik sumber daya manusia maupun faktorfaktor produksi lainya. 2) Proses yang bertahap mulai dari perencanaan, pengorganisasian, pengarahan dan pengimplementasian, hingga pengendalian dan pengawasan. 3) Adanya seni dalam penyelesaian pekerjaan.

Jadi dapat disimpulkan bahwa pengelolaan (manajemen) adalah suatu cara atau proses yang dimulai dari perencanaan, pengorganisasian, pengawasan dan evaluasi untuk mencapai suatu tujuan yang telah ditentukan agar berjalan efektif dan efisien.

\section{Konsep Retribusi Daerah}

Penerimaan pemerintah daerah selain dari pajak daerah dan bagi hasil pajak pusat yang diperuntukkan ke pemerintah daerah berasal dari retribusi daerah. Akan tetapi, untuk retribusi tiap daerah memiliki potensi yang berbeda satu sama lain, untuk itu pemerintahan daerah harus dapat melihat peluang apa saja yang dapat dilakukan dalam menggali penerimaan dari retribusi untuk menunjang penerimaan.

Menurut Marihot Siahaan (dalam Mustafa L. \& Elwan L.O.M;2018 : 18-31), terdapat beberapa ciri yang melekat pada retribusi daerah yang saat ini dipungut di Indonesia adalah sebagai berikut :

1) Retribusi merupakan pungutan yang dipungut berdasarkan Undang- Undang dan Peraturan Daerah yang berlaku;

2) Hasil penerimaan retribusi masuk ke kas pemerintah daerah. Pihak yang membayar retribusi mendapatkan kontraprestasi (balas jasa) secara langsung dari pemerintah daerah atas pembayaran yang dilakukannya;

3) Retribusi terutang apabila ada jasa yang diselenggarakan oleh pemerintah daerah yang dinikmati oleh orang atau badan;

4) Sanksi yang dikenakan pada retribusi adalah sanksi secara ekonomis, yaitu jika tidak membayar retribusi, tidak akan memperoleh jasa yang diselenggarakan oleh pemerintah daerah.

Dalam pengertian tersebut, menjelaskan bahwa Restibusi Pasar adalah bagian yang tidak terpisahkan dari sumber-sumber pendapatan daerah. Olehnya itu, dperlukan pengelolaan secara profesional, terukur, dan dapat dipertanggung jawabkan.

\section{Konsep Pajak Retribusi}

Menurut UU No.28 Tahun 2007 Pasal 1 Tentang Ketentuan Umum dan Perpajakan, pajak merupakan suatu konstribusi wajib kepada negara yang terhutang oleh setiap orang maupun badan yang sifatnya memaksa namun tetap berdasarkan pada Undang-Undang, dan tidak mendapat imbalan secara langsung serta digunakan untuk kebutuhan negara juga kemakmuran rakyatnya. Menurut Rochmat Soemitro (dalam Mustafa L. \& Elwan L.O.M; 2018 : 18-31), pajak ialah iuran rakyat kepada negaranya berdasarkan Undang-Undang atau peralihan kekayaan dari sektor swasta kepada sektor publik yang bisa dipaksakan dan yang 
langsung dapat ditunjuk serta digunakan untuk membiayai kebutuhan atau kepentingan umum.

Menurut bahasa Retribusi adalah bagian jalan bersebelahan dengan jalur gerak untuk akomodasi kendaraan yang berhenti, untuk penggunaan darurat dan untuk penyangga lateral dasar dan permukaan bahu. Namun dari persfektif Pajak Retribusi parkir yang dimaksud adalah kontribusi atau iuran masyarakat pemilik mobil angkutan dan barang dalam menggunakan jalan raya sebagai akses dalam menjalankan aktivitas mereka.

Berdasarkan hal tersebut maka, Pajak Retribusi Parkir yang dimaksud dalam penelitian ini adalah sejumlah nilai uang yang harus dibayarkan oleh para pemgguna parkir yang melakukan aktivitas ekonomi dalam menggunakan jalan raya dan area parkir tersebut seperti mobil pribadi, angkutan umum dan angkutan barang dari dalam kota maupun luar kota. Harapannya adalah pajak restribusi parkir tersebut dapat menjadi sumber pendapatan daerah dalam pembiyaan pembangunan.

\section{Retribusi Pasar}

Menurut Kesit Bambang, (2005:135) pengertian retribusi pasar adalah retribusi atas fasilitas pasar tradisional/sederhana yang berupa pelataran atau los yang dikelola pemerintah daerah dan khusus disediakan untuk pedagang, tidak termasuk yang dikelola perusahaan daerah pasar.

Retribusi pasar atau retribusi pelayanan pasar merupakan salah satu jenis Retribusi jasa umum yang keberadaannya cukup dimamfaatkan oleh masyarakat. Menurut penjelasan Peraturan Pemerintah No. 66 Tahun 2001 yang dimaksud pelayanan pasar adalah fasilitas pasar tradisional atau sederhana berupa pelataran, los yang dikelola pemerintah daerah, yang khusus disediakan untuk pedagang, tidak termasuk yang dikelola oleh Badan Usaha Milik Daerah dan Pihak Swasta. Fasilitas-fasilitas lain yang dikelola oleh pemerintah daerah untuk pedagang yaitu keamanan, penerangan umum, penyediaan air, telepon, kebersihan dan penyediaan alat-alat pemadam kebakaran.

Adapun yang menjadi subyek dari retribusi pasar adalah orang pribadi atau badan yang menggunakan fasilitas pasar. Sedangkan obyek retribusi pasar meliputi:

1. Penyediaan fasilitas pasar/tempat (Kios, Los, front Toko, dan Pelataran) pada pasar yang disediakan oleh pemerintah daerah.

2. Setiap kegiatan membongkar muatan hasil bumi, laut, ternak, dan barang dagangan lainnya pada radius 200 meter dari pasar.

3. Keramaian pasar.

4. Biaya balik nama pemakai.

Dalam pelaksanaannya retribusi jasa umum harus memenuhi kriteria sebagai berikut:

1. Retribusi ini bersifat bukan pajak dan bersifat bukan retribusi jasa usaha atau retribusi perizinan tertentu.

2. Jasa yang bersangkutan merupakan kewenangan daerah dalam rangka pelaksanaan desentralisasi.

3. Jasa tersebut memberikan mamfaat khusus bagi orang pribadi atau badan yang diharuskan untuk membayar retribusi disamping untuk melayani kepentingan dan kemamfaatan umum.

4. Jasa tersebut layak untuk dikenakan retribusi.

5. Retribusi tidak bertentangan dengan kebijakan nasional tentang pelaksanaannya.

6. Retribusi dapat dipungut secara efektif dan efisien, serta merupakan salah satu sumber pendapatan daerah yang potensial.

7. Pemungutan retribusi memungkinkan penyediaan jasa tersebut dengan tingkat dan kualitas layanan yang baik. (Suandy, 2002:269)

\section{Kerangka Pikir}

\begin{tabular}{|c|c|c|}
\hline MANAJEMEN & & PAD \\
\hline $\begin{array}{l}\text { 1. Planning (Perencanaan), } \\
\text { 2. Organizing (Pengorganisasian), } \\
\text { 3. Actuating (Pelaksanaan) } \\
\text { 4. Controlling (Pengawasan). } \\
\text { (George R. Terry dalam Sukarna, } \\
2011 \text { : 10) }\end{array}$ & $\Rightarrow$ & $\begin{array}{c}\text { Restribusi Pasar Lapulu } \\
\text { Kota Kendari }\end{array}$ \\
\hline
\end{tabular}

Gambar 1. Kerangka Pikir Penelitian 
Vol 2 No 3 August-October 2019. pp.32-41. Journal PUBLICUHO Faculty of Social and Political Sciences Halu Oleo University, Kendari, Southeast Sulawesi, Indonesia. ISSN 2621-1351 (online), ISSN 2685-0729 (print) Open Access at:

http://ojs.uho.ac.id/index.php/PUBLICUHO/index

\section{METODE PENELITIAN}

Penelitian ini dilaksanakan di Pasar Lapulu Kota Kendari, Penelitian dengan menggunakan pendekatan Deskriptif kualitatif, menghasilkan data berupa kata-kata tertulis atau lisan dari orang-orang dan perilaku yang dapat di amati.dengan metode yang di gunakan menekankan pada proses penelusuran data/informasi hingga di rasakan telah cukup digunakan untuk membuat suatu interpretasi. Tipe penelitian deskriptif yaitu bertujuan untuk mendeskripsikan secara terperinci mengenai fenomena-fenomena sosial tertentu yang berkenaan dengan masalah dan untuk ditelitidengan Teknik analisis data yang dipergunakan dalam penelitian ini adalah teknik deskriptif menurut Miles dan Huberman dalam Sugiyono (2016:246) dengan membuat gambaran yang dilakukan dengan cara (1) reduksi data atau penyederhanaan (data reduction), (2) paparan/sajian data (data display), dan (3) penarikan kesimpulan

\section{HASIL DAN PEMBAHASAN}

\section{Manajemen Pengelolaan Retribusi Pasar Dalam Meningktakan Pendapatan Asli Daerah}

\section{Perencanaan (Planning)}

Planning berasal dari kata plan, artinya rencana, rancangan, maksud, dan niat. Planning berarti perencanaan. Perencanaan adalah proses kegiatan, sedangkan rencana merupakan hasil perencanaan. Perencanaan adalah kegiatan yang berkaitan dengan usaha merumuskan program yang di dalamnya memuat segala sesuatu yang akan dilaksanakan, penentuantujuan, kebijakan, arah yang akan ditempuh, prosedur dan metode yang akan diikuti dalam usaha pencapaian tujuan.

Tabel 1. Target Penerimaan Jasa PKD Kios Periode Tahun 2018

\begin{tabular}{cccccccc}
\hline No. & Ukuran & Luas $\left.\mathbf{( m}^{\mathbf{2}}\right)$ & Besaran PKD/BIn & No. & Ukuran & Luas $\left.\mathbf{( m}^{\mathbf{2}}\right)$ & Besaran PKD/BIn \\
\hline 1 & $2,70 \times 8$ & 21,6 & Rp. 131.400,- & 10 & $5 \times 3,5$ & 17,5 & Rp. 106.500,- \\
\hline 2 & $2,70 \times 4$ & 10,8 & Rp. 65.700,- & 11 & $2 \times 3,5$ & 7 & Rp. 42.600,- \\
\hline 3 & $1,70 \times 3$ & 5,1 & Rp. 31.000,- & 12 & $4 \times 8$ & 32 & Rp. 194.700,- \\
\hline 4 & $1,70 \times 6$ & 10,2 & Rp. 62.000,- & 13 & $3 \times 6$ & 18 & Rp. 109.500,- \\
\hline 5 & $2 \times 3$ & 6 & Rp. 36.500,- & 14 & $4 \times 5$ & 20 & Rp. 121.700,- \\
\hline 6 & $3 \times 3$ & 9 & Rp. $54.750,-$ & 15 & $3 \times 2,5$ & 7,5 & Rp. 45.625,- \\
\hline 7 & $3 \times 4$ & 12 & Rp. 73.000,- & 16 & $4 \times 2$ & 8 & Rp. 48.700,- \\
\hline 8 & $3 \times 8$ & 24 & Rp. 146.000,- & 17 & $2 \times 2$ & 4 & Rp. 24.350,- \\
\hline 9 & $3 \times 4,5$ & 13,5 & Rp. 82.125,- & 18 & $4 \times 4$ & 16 & Rp. 97.350,- \\
\hline
\end{tabular}

Sumber : Unit Pasar Lapulu Kota Kendari, 2018

Tabel 2. Data Buku Kontrol Penerimaan Jasa PKD Lods Unit Pasar Lapulu Periode Tahun 2018

\begin{tabular}{cccc}
\hline No. & Ukuran & Luas $\left.\mathbf{( m}^{\mathbf{2}}\right)$ & Besaran PKD/BIn \\
\hline 1 & $1 \times 2$ & 2 & Rp. 12.200,- \\
\hline 2 & $1,5 \times 1,5$ & 2,25 & Rp. 13.700,- \\
\hline 3 & $2 \times 2$ & 4 & Rp. 24.350,- \\
\hline 4 & $2 \times 4$ & 8 & Rp. 48.700,- \\
\hline \multicolumn{4}{c}{ Sumber: Unit Pasar Lapulu Kota Kendari, 2018 }
\end{tabular}

Tabel 3. Data Penerimaan Jasa PKD Eks TPS Unit Pasar Lapulu Priode Tahun 2018

\begin{tabular}{cccc}
\hline No. & Ukuran & Luas $\left(\mathbf{m}^{\mathbf{2}}\right)$ & Besaran PKD/Bln \\
\hline 1 & $2 \times 2$ & 4 & Rp. 24.300,- \\
\hline 2 & $2 \times 3$ & 6 & Rp. 36.500,- \\
\hline \multicolumn{4}{c}{ Sumber: Unit Pasar Lapulu Kota Kendari, 2018 }
\end{tabular}


Pasar Kota Kendari dan Unit Pasar Lapulu Kota Kendari hanya melaksanakan Perencanaan yang telah ditetapkan di Perusahaan Daerah itu sendiri. Dan berdasarkan Perencanaan yang dilaksanakan oleh Unit Pasar Lapulu itu sendiri masih memiliki hambatan dimana hambatan itu adalah kesadaran pedagang yang masih kurang dan keramaian pasar di harihari tertentu saja sehingga menjadi salah satu hambatan dalam suatu perencanaan.Jika dikaitkan dengan teori yang digunakan oleh George R. Terry adalah menghubungkan faktafakta, membuat asumsi-asumsi tentang masa depan disertai perumsan aktivitas yang akan dilaksanakan untuk mencapai tujuannya dimana perencanaan untuk pasar Lapulu Kota Kendari telah dilakukan sesuai prosedur

Mengenai perencanaan di pasar Lapulu Kota Kendari yang di lakukan oleh PD. Pasar Kota Kendari bahwa wewenang untuk melaksanakan adalah Kepala Unit Pasar Lapulu Kota Kendari yang dimana salah satu perencanaan itu ialah perencanaan target dan perencanaan sarana dan prasarana di pasar Lapulu kota Kendari

perencanaan dalam hal penentuan target yang telah direncanakan oleh perusahaan daerah pasar kota kendari disusun sudah optimal. Hal ini dapat dilihat dari telah ditentukan dan dilaksanakannya penarikan wajib retribusi setiap tahun, namun realisasi yang terkadang tidak mencapai target disebabkan oleh para pedagang yang sering menunggak pembayaran retribusi secara rutin dengan berbagai alasan.

\section{Sarana dan Prasarana di Pasar Lapulu Kota Kendari}

penyediaan sarana dan prasarana di pasar lapulu sudah baik dan mempermudah aktivitas jual beli yang terjadi di pasar pada umumnya hanya saja ada beberapa pihak ataupun beberapa orang yang masih saja belum mampu menjaga prasarana yang telah disediakan oleh pihak Unit Pasar Lapulu Kota Kendari dan itu selalu saja menjadi masalah yang selalu terjadi secara berulang-ulang. Jika di kaitkan dengan teori sarana dan prasarana di pasar lapulu sudah sanget memenuhi standar di mana penyediaan saran dan prasarananya telah disediakan oleh unit pasar lapulu untuk kepentingan pedagang maupun pengujung yang ada di Pasar lapulu peralatan, perlengkapan dan fasilitas yang berfungsi sebagai alat utama/pembantu dalam pelaksanaan tujuan, dan juga dalam rangka kepentingan yang sedang berhubungan dengan organisasi kerja. sarana dan prasarana adalah merupakan seperangkat alat yang digunakan dalam suatu proses kegiatan baik alat tersebut adalah merupakan peralatan pembantu maupun peralatan utama, yang keduanya berfungsi untuk mewujudkan tujuan yang hendak dicapai.

\section{Pengorganisasian (Organizing)}

pengorganisasian berasal dari kata organize yang berarti menciptakan struktur dengan bagian-bagian yang diintergrasikan sedemikian rupa, sehingga hubugannya satu sama lain terikat oleh hubungan terhadap keseluruhannya. Pada penelitian yag dilaksanakan bahwa Kantor Unit Pasar Lapulu Kota Kendari yang melakukan penagihan retribusi pasar, pasar lapulu memiliki kolektor serta membagi wilayah kerja masing-masing kolektornya untuk memungut retribusi adalah salah satu bentuk pengorganisasian yang dilakukannya. Pada Kantor Unit Pasar Lapulu Kota Kendari ini bagian penagihan dilakukan oleh kolektor saja. Semua kolektor itu pergi melakukan atau managih retribusi sesuai dengan tugasnya yaitu memungut dan mengendalikan retribusi". Dari beberapa hasil wawancara dapat ditarik kesimpulan bahwa penagih retribusi untuk Pasar Lapulu Kota Kendari terdiri dari beberapa kolektor dimana kolektor memiliki fungsi yang sama. Untuk jumlah dan pembagian tugas kolektor sudah efektif karena pembagian wilayah kerja kolektor dan jumlah kolektor yang sudah cukup sedangkan untuk staf yang menarma retribusi berjumlah satu orang saja dan dilihat berdasarkan tugasnya

\section{Pelaksanaan/Pengendalian}

Pelaksanaan merupakan terjemahan dari bahasa Inggris Actuating, dimana kata ini berasal dari actuare bahasa Latin. Istilah actuating secara harfiah dapat diartikan sebagai suatu tindakan membuat orang-orang bergerak untuk melakukan aktifivas-aktifitvas. Actuating ini merupakan fungsi yang penting, karena pelaksanaan fungsi ini berhubungan denganmanusia sebagai objek langsungnya. Sehubungan dengan pengendalian di pasar lapulu kota kendari bahwa mereka melakukan pengendalian dengan secara kolektif dengan maksud bahwa pengendalian dilakukan salah satunya dengan cara memperkiraan apa saja 
Vol 2 No 3 August-October 2019. pp.32-41. Journal PUBLICUHO Faculty of Social and Political Sciences Halu Oleo University, Kendari, Southeast Sulawesi, Indonesia. ISSN 2621-1351 (online), ISSN 2685-0729 (print) Open Access at:

http://ojs.uho.ac.id/index.php/PUBLICUHO/index

yang kurang dalam dalam suatu perencanaan dan dilakukan dengan inisiatif mereka. Jika dikaitkan di atas menurut George R. Terry ialah pelaksanaan ialah membangkitkan dan mendorong semua anggota kelompok agar supaya berkehendak dan berusaha dengan keras untuk mencapai tujuan dengan ikhlas serta serasi dengan perencanaan dan usahausaha pengorganisasian dari pihak pimpinan Kantor Unit Pasar Lapulu Kota Kendari selalu memotivasi dan menggerakkan pegawainya terkhusus kolektor dan staf agar melaksanakan kewajibannya dengan tepat dan rajin agar para kolektor dapat mencapai target yang telah di tetapkan oleh perusahaan daerah Kota Kendari.

\section{Pengawasan (Controlling)}

Pengawasan adalah suatu kegiatan untuk mencocokkan apakah kegiatan operasional (actuating) di lapangan sesuai dengan rencana (planning) yang telah ditetapkan dalam mencapai tujuan (goal) dari organisasi, Dengan demikian yang menjadi obyek dari kegiatan pengawasan adalah mengenai kesalahan, penyimpangan, cacat dan hal-hal yang bersifat negatif. Sehubungan dengan pengawasan pihak Unit Pasar Lapulu Kota Kendari selalu mengadakan evaluasi kerja di mana mereka selalu mengecek apakah pelaksanaan yang dilakukan sudah sesuai dengan perencanaan ataupun tidak sehingga mereka selalu mengadakan evaluasi setiap bulan terhadap pelaksanaan yang di lakukan. pengawasan di Pasar Lapulu Kota Kendari yang selalu memantau para pegawainya terutama kolektor di pasar Lapulu agar dapat mengetahui jika ada penyimpangan yangb terjadi dalam perencanaan yang ada sesuai dengan standard yang ada.

\section{Pengelolaan Retribusi Pasar dalam Meningkatkan Pendapatan Asli Daerah di Kota Kendari}

Retribusi pasar dipungut oleh Kolektor yang ada disetiap Unit Pelaksana Teknis Dinas (UPTD) pasar dengan menggunakan alat bukti pembayaran berupa karcis yang telah tercantum dalam Surat Ketetapan Retribusi Daerah. Dalam hal pembayaran dari keseluruhan jumlah retribusi yang harus dibayar dan ditagih dengan Surat Tagihan Retribusi Daerah (STRD), hal ini berdasarkan Peraturan Walikota Kota Kendari Nomor 02 Tahun 2012 tentang Retribusi Jasa Umum. Pengelolan Restribusi pasar dalam meningkatkan PAD di Kota Kendari salah satunya dapat di jelaskan dalam Alur Penyetotan Restribusi Pasar Lapulu Kota Kendari seperti pada Gambar 2.

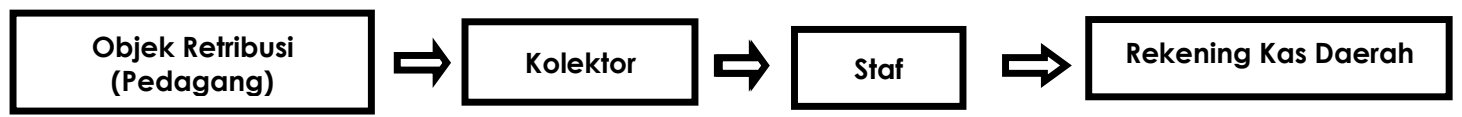

Gambar 2. Alur Penyetoran Restribusi Pasar Lapulu Kota Kendari

Alur penyetoran retribusi pasar yang berawal dari juru tagih/kolektormenarik retribusi dengan objek retribusi atau pedagang lalu setelah terkumpul, juru tagih memberikan setoran atau sejumlah uang retribusi ke stafpasar masing-masing yang kemudian uang yang telah dihitung keabsahannya oleh staf pasar tersebut lalu dilimpahkan ke bank atau lansung masuk ke Rekening kas daerah yang ada di kota kendari yang kemudian di setor ke bagian penerimaan retribusi yang akan di jadikan sebagai pendapatan daerah melalui kas daerah.

Pengelolan Restribusi pasar dalam meningkatkan PAD di Kota Kendari, di sesuaikan dengan Peraturan Walikota Kota Kendari Nomor 2 Tahun 2012 tentang Tata Cara Pelaksanaan Pemungutan Retribusi Pelayanan Pasar, retribusi pasar dikenakan kepada pedagang yang memanfaatkan fasilitas pasar. Fasilitas pasar yang dikenakan retribusi pasar adalah berupa los, kios yang dikelola pemerintah daerah dan khusus disediakan untuk pedagang.

Tabel 4. Struktur dan Besarnya Tarif Retribusi Pelayanan Pasar di Pasar Lapulu

\begin{tabular}{cccc}
\hline No & Jenis Tempat & Tarif (Rp) & Frekuensi Waktu \\
\hline 1 & Kios & 2.500 & Per hari \\
\hline 2 & Lods & 2.000 & Per hari \\
\hline 3 & Lapak & 2.000 & Per hari \\
\hline & Sumber: Unit Pasar Lapulu Kota Kendari, 2018 &
\end{tabular}


Sehubungan dengan ketentuan tariff retribusi yang di pungut oleh pihak kolektor Unit Pasar Lapulu Kota Kendari menyangkut pemungutan retribusi di pasar lapulu sangat jarang sekali terjadi penunggakan yang dilakukan oleh pedagang di pasar lapulu karena setiap pedagang mengetahui sangat pentingnya dan wajib membayar retribusi yang telah di tetapkan oleh perusahaan daerah tetapi selalu saja ada kendala di mana kendala tersebut adalah kurang ramainnya pengunjung pada hari-hari biasa yang mengakibatkan pedagang sering menunda atau menunggu barang dagangan mereka laku dan setelah itu barulah mereka membayar retribusi. Pembayaran retribusi pasar merupakan bentuk dan bukti perwujudan dalam pembiayaan negara dan pembangunan nasional. Hal ini dimaksudkan untuk tercapainya penerimaan Pendapatan Asli Daerah (PAD) dari sector retribusi pasar di Kota Kendari yang memberikan kontribusi untuk menunjang pembangunan daerah dan peningkatan penerimaan Pendapatan Asli Daerah.

Tabel 5. PD. Pasar Kota Kendari Target dan Penerimaan Retribusi

\begin{tabular}{cccc}
\multicolumn{4}{c}{ Unit Pasar Lapulu Kota Kendari periode Jan/Des 2018 } \\
\hline Tahun & Target & Realisasi & $\%$ \\
\hline 2016 & Rp. 534.900.000 & Rp. 437.675.000 & 123 \\
\hline 2017 & Rp. 472.334.190 & Rp. 450.400.000, & 95 \\
\hline 2018 & Rp. 731.988.600 & Rp. 505.440.175 & 69, \\
\hline
\end{tabular}

Sumber : Unit Pasar Lapulu Kota Kendari, 2018

Berdasarkan target dan penerimaan Retribusi pasar Lapulu Kota Kendari bahwa Pasar Lapulu tidak mencapai target dari 3 (tiga) tahun terakhir walaupun jumlah realisasi penerimaan retribusi selalu meningkat setiap tahunnya.

\section{KESIMPULAN}

Kesimpulan dari penelitian ini adalah bahwa penerapan manajemen retribusi pasar dalam meningkatkan Pendapatan Asli Daerah di pasar Lapulu di Kota Kendari tidak efektif karena kurangnya pengumpulan pungutan wajib yang intensif, tunggakan pembayaran pungutan oleh pedagang karena berbagai alasan sehingga realisasi retribusi pasar tidak mencapai target yang direncanakan.

\section{SARAN}

Berdasarkan kesimpulan penelitian, saran dari hasil penelitian ini adalah:

1. Manajemen Pengelolaan Retribusi Pasar lebih ditingkatkan terutamadalam hal pengendalian yang menekankan pada sikap dan motivasi bagi yang terlibat dalam organisasi sehingga dapat mencapai tujuan yang telah di tetapkan dan selalu melakukan pengawasan kepada anggota organisasi setiap minggunya.

2. Manajemen Pengelolaan Retribusi Pasarharus lebih maksimal sehingga realisasi penerimaan retribusi pasar dapat mencapai target yang telahditetapkan sehingga dapat lebih berkontribusi dalam meningkatkanPendapatan Asli Daerah.

3. Manajemen Pengelolaan Retribusi Pasarterkait dengan kegiatan pemungutan retribusipasar semua petugas retribusi harus sesuai dengan prosedur dan tegas saat menagih retribusi pasar terhadap pedagangsebagai wajib retribusi. 
Vol 2 No 3 August-October 2019. pp.32-41. Journal PUBLICUHO Faculty of Social and Political Sciences Halu Oleo University, Kendari, Southeast Sulawesi, Indonesia. ISSN 2621-1351 (online), ISSN 2685-0729 (print) Open Access at: http://ojs.uho.ac.id/index.php/PUBLICUHO/index

\section{DAFTAR PUSTAKA}

Bambang, Prakosa, Kesit, 2005, Pajak dan Retribusi Daerah, Yogyakarta, UII Press.

D, Riant, Nugroho.. 2004. Kebijakan Publik, Formulasi Implementasi dan Evaluasi. Jakarta: Gramedia.

Erly Suandy 2002.Perpajakan. Jakarta: SalembaEmpat

Mustafa L., \& Elwan, L.O.M. 2018. Implementasi Pengelolaan Pajak Restribusi Parkir Di Kota Kendari. ( Journal Publicuho, 1 (4), 18-31.

http://ojs. uho. ac. id/index. php/PUBLICUHO/article/view/6318

DOI: http://dx.doi.org/10.35817/jpu.v1i4.6318)

Moleong,L.J.(2011). Metodologi Penelitian Kualitati fEdisiRevisi. Bandung: PTRemajaRosdakarya. Peraturan Daerah Kota KendariNomor 2 Tahun 2012 tentang Retribusi Jasa Umum Sugiyono. 2014. Metode penelitian Kulitatif, Kuantitatif dan R\&D. Bandung:Alfabeta

Timbul Hamonangan Simanjuntak dan Imam Mukhlis, 2012.Dimensi Ekonomi Perpajakan dalam Pembangunan Ekonomi, Raih Asa Sukses, Jakarta. 